\title{
MORAL SENSITIVITY, ETHICAL EXPERIENCES AND RELATED FACTORS OF PEDIATRIC NURSES: A CROSS-SECTIONAL, CORRELATIONAL STUDY
}

\begin{abstract}
Fatma Tas Arslan ${ }^{1}$, Pelin Calpbinici ${ }^{2}$
Abstract: The aim of this study is to determine the ethical experiences and the level of moral sensitivity and related factors of pediatric nurses working in hospital settings. Designed as descriptive and cross-sectional, the study was undertaken at three public hospitals in Konya and Ankara, Turkey and included the participation of a total of 200 pediatric nurses. The Moral Sensitivity Questionnaire (MSQ) was used for evaluation of the ethical sensitivities of the nurses. Of the 200 nurses, $46.5 \%$ had working experience of between 1-5 years, $58 \%$ were married, $18.6 \%$ had not undergone any ethics education, and $59.5 \%$ held a bachelor's degree. A large majority (95\%) of the pediatric nurses reported that they had encountered ethical problems. The mean moral sensitivity score of the nurses was $95.89 \pm 24.34$, with higher scores in this area being observed in the nurses who were in the older age group and had worked longer than others $(\mathrm{p}<0.05)$. The mean moral sensitivity score of the nurses was determined to be at a medium level and was found to be influenced by the age group they were in and the length of time they had worked.
\end{abstract}

Key words: ethics, moral sensitivity, ethical experiences, pediatric nurses, nursing ethics

\section{Sensibilidad moral, experiencias éticas y factores relacionados de enfermeras pediatras: un estudio transversal de correlación}

Resumen: El objetivo de este estudio consiste en determinar las experiencias éticas y el nivel de sensibilidad moral y factores relacionados de enfermeras pediatras que trabajan en hospitales. El diseño del estudio es descriptivo y transversal y se realizó en tres hospitales públicos en Konya y Ankara en Turquía, incluyendo la participación de un total de 200 enfermeras pediatras. Para evaluar la sensibilidad ética de las enfermeras se usó el Cuestionario sobre Sensibilidad Moral (CSM). De las 200 enfermeras, $46,5 \%$ tenía experiencia de trabajo entre uno y cinco años, 58\% era casada, 18,6\% no había recibido educación en ética y $59,5 \%$ era licenciada. Una gran mayoría (95\%) de las enfermeras pediatras informó que había experimentado problemas éticos. El puntaje medio de sensibilidad moral fue de $95.89 \pm 24.34$, con puntajes más altos para las enfermeras de mayor edad y que habían trabajado más tiempo $(\mathrm{p}<0.05)$. Se determinó que el puntaje medio de sensibilidad moral era de nivel medio y que estaba influenciado por el grupo etario y el tiempo de experiencia de trabajo.

Palabras clave: ética, sensibilidad moral, experiencias éticas, enfermeras pediatras, ética de enfermería

\section{Sensibilidade moral, experiências éticas e fatores relacionados da enfermagem pediátrica: um estudo transversal correlacional}

Resumo: O objetivo deste estudo é determinar as experiências éticas e o nível de sensibilidade moral e fatores relacionados da atuação da enfermagem pediátrica no ambiente hospitalar. Concebido como descritivo e transversal, o estudo foi realizado em três hospitais públicos em Konya e Ankara (Turquia) e contou com a participação de um total de 200 enfermeiros pediátricos. O questionário de sensibilidade Moral (MSQ) foi usado para avaliar a sensibilidade ética dos enfermeiros. Dos 200 enfermeiros, 46,5\% tinham experiência profissional entre 1 a 5 anos, 58\% eram casados, 18,6\% não tinham qualquer instrução de estudos de ética e 59,5\% tinham graduação. Uma grande maioria (95\%) dos enfermeiros pediatras relataram que já encararam problemas éticos. A pontuação média acerca da sensibilidade moral dos enfermeiros foi de $95.89 \pm 24.34$, com notas mais altas no grupo em que os enfermeiros estavam na faixa etária mais velha e tinham trabalhado mais do que outros $(\mathrm{p}<0,05)$. A pontuaçáo média de sensibilidade moral dos enfermeiros foi determinada em um nível médio e foi identificada pela influência da faixa etária e de tempo que tinham trabalhado.

Palavras-chave: ética, sensibilidade moral, experiências éticas, enfermeiros pediátricos, ética na enfermagem

\footnotetext{
${ }^{1}$ Associate Professor, PhD, Selcuk University, Faculty of Health Sciences, Konya, Turkey

${ }^{2}$ Research Assistant, Nevsehir Hacı Bektaş Veli University, Semra and Vefa Küçük Health College, Nevsehir, Turkey

Correspondence: pelince2@yandex.com
} 


\section{Introduction}

While advances in technology and health-care services have improved the quality of patient care and given individuals greater control over their lives, they have also caused certain ethical issues to emerge. Over time, these ethical issues have gradually taken on greater importance within the field of health(1). In a general sense, the concept of ethics can be defined as the system of moral principles, values and standards governing the notions of costs and benefits, good and bad, and right and wrong and the determination of how these notions unfold in individual and group behavior relationships(2).

The health team is responsible for providing highquality care to ensure the well-being of the patient(3). As indispensable members of this team, nurses are in close communication with the patient and occupy a role wherein they witness the most sensitive, private, personal and weakest aspects of patients, as well as their feelings, such as pain, sorrow, loneliness and despair. In fulfilling this role, nurses may occasionally be required to take actions on behalf of patients and make decisions based on ethical judgement(4). It is during this process in particular that nurses may encounter a greater number of ethical problems(5), such as those related to the protection of patient rights, the value systems applied by nurses, limited capacity of nurses to fulfil appropriate ethical requirements, institutional opposition, institutional coercion, institutional profit factors, financial matters that may prohibit a patient from receiving medical service, provision of care for terminal patients, informed consent, share of limited resources, and different opinions among physicians about care and treatment of patients $(6,7)$.

Children, as naturally understood, are biologically, psychologically and socially different from adults. Since their cognitive and intellectual levels are not fully developed, the protection of children's autonomy is a primary concern. Decisions about acceptance of treatment and participation in research for children acquires a different character, insofar as these decisions embody a tripartite relationship between the "medical team child - parents/guardian", as opposed to the dual relationship of "medical team - patient" $(8,9)$.
Furthermore, quality of life, physicians' paternal approach versus parents' autonomy, and anxieties about treatments requiring advanced technology can all affect decisions(10-12). Under these circumstances, the most important questions for pediatric nurses to ask are "Who will make the decision about the child?", "How will the child participate in the decision making process?" (13) and "What is best for the child?".

As children have limited autonomy, nurses working in pediatric clinics have direct, unavoidable responsibilities regarding the rights of their pediatric patients(14). It is at this point that the pediatric nurse is able to prevent potential ethical conflicts by establishing effective communication between the parents and other members of the medical team and/or by preparing them to face any future problems(15). Being a dynamic process, this situation can only be managed through the combination of logical and ethical decisionmaking, which depends on the ability to think and the development of moral sensitivity.

Moral sensitivity in the health-care field requires that nurses be skilled in moral decision-making and in the management of diverse ethical issues in clinical settings(16). Proper moral sensitivity not only functions to resolve ethical dilemmas or justify actions, but also serves to prevent ethical dilemmas and conflicts(17). Furthermore, moral sensitivity acts a core component of the integrity that a nurse should possess in caring for patients who are in need of their professional healthcare service(18). When pediatric nurses behave with high moral sensitivity, this both contributes to professionalization and directly affects the quality of nursing care provided to patients(19). With that said, the aim of this study is to determine the level of moral sensitivity in pediatric nurses and the factors affecting it. Results from this study shall therefore make a significant contribution towards the practice of morally sensitivity by pediatric nurses.

The research questions developed for this study were as follows:

- What are the ethical experiences of pediatric nurses? 
- What are the moral sensitivity levels of pediatric nurses?

- Do moral sensitivity levels differ according to certain sociodemographic and professional variables of pediatric nurses?

\section{Method}

\section{Participants}

This descriptive, cross-sectional and correlational study was performed in the city centers of Konya (at public and children's hospitals) and Ankara (at children's hospital), Turkey between March 2012 and June 2012. The population of the study consisted of 470 nurses working in the pediatric clinics of two hospitals. The study sample was reduced to a total of $200(43 \%)$ nurses due to the failure of 15 nurses to fill out data forms completely and 255 nurses declining to participate in the study.

\section{Instruments}

A general information questionnaire form, developed by the researchers in line with the literature, was used for data collection $(8,20)$. The information form consisted of two parts. The first part included a total of 22 questions that aimed to determine the nurses' sociodemographic and professional characteristics and experiences about professional ethics (12 questions about the sociodemographic and professional characteristics of nurses, such as age, gender, marital status, and educational background, and 10 questions about their experiences regarding professional ethics, such as the reason behind the experience of an ethical problem, the person or party with whom the ethical problem was experienced and the attitudes expressed in solving the ethical problem). In addition, the Moral Sensitivity Questionnaire (MSQ) was used to evaluate the ethical sensitivities of the nurses.

The MSQ was developed by Lutzen(21) for the purpose of measuring moral sensitivity. The questionnaire is a seven-point Likert scale, involving 30 items arranged under six subscales: autonomy (respect for the principle of autonomy and patient preferences), benevolence (the actions ai- med at improving the well-being of the patient), holistic approach (the actions performed to prevent harm to the patient and to protect their integrity), conflict (the experience of inner ethical conflicts), practice (consideration of the ethical dimension in deciding on an action and practice) and orientation (the interests of healthcare professionals as they pertain to actions that may affect their relationship with the patient) (22). Responses to items in the questionnaire range between 1 (strongly agree) and 7 (strongly disagree), with 1 signifying high moral sensitivity and 7 signifying low moral sensitivity. The total possible attainable scores range between 30 and 210. Higher total point scores indicate low ethical sensitivity, while lower total point scores indicate high ethical sensitivity. In the validity and reliability studies of the Turkish version of the questionnaire conducted by Tosun(22), Cronbach's alpha value was found to be 0.84 . In the present study, Cronbach's alpha value was determined to be 0.87 .

\section{Procedures}

Before starting the study, a preliminary application was administered to 10 pediatric nurses. After their completion of this application, it was determined no changes were necessary. The acquired data from this preliminary application were therefore included in the study data. The data collection form was delivered to the pediatric nurses, who had seven days to fill it out, and then collected from them by the researcher.

\section{Data Analysis}

For data analysis, the Statistical Package for the Social Sciences, version 22.0 (SPSS; IBM, New York, NY), was used. The data were defined as number, percentage, mean, and SD. Comparisons between groups were performed with the Student's t-test, and one-way analysis of variance was used for data showing normal distribution. Data not showing normal distribution were assessed using the Mann-Whitney U and the Kruskal-Wallis non-parametric tests. For all analyses, $\mathrm{p}<0.05$ was considered to be significant.

\section{Ethical Considerations}

The required institutional permissions were ob- 
tained from the hospitals where the study was conducted. Prior to obtaining their verbal consents, the nurses who were included in the sample were informed about the objective and subject of the study and told that their participation was based on the principle of voluntariness.

\section{Results}

Of the 200 nurses, $53.5 \%$ fell within the $18-30$ age group, $38 \%$ within the $31-40$ age group and $8.5 \%$ within the 41 and older age group. Over half of the nurses (58\%) were married, but most of them did not have any children (53.5\%). A majority of the nurses $(59.5 \%)$ had bachelor's degree and about half (46.5\%) had been working between 1-5 years as a professional nurse.

In this study, a large majority of the nurses (74\%) reported that they had occasionally encountered ethical problems; these included ethical problems related to disease $(41.6 \%)$, care practices $(12.2 \%)$, medications $(6.3 \%)$ and all of the above $(20.8 \%)$. It was found that $63.5 \%$ of the nurses reported feeling sufficient in realizing and solving ethical problems (see Table 1). More than half of the nurses $(61.5 \%)$ stated that they had experienced ethical problems in dealing with families of children, $27.6 \%$ with physicians and $26.7 \%$ with their colleagues. In examining the reasons responsible for the ethical problems experienced by pediatric nurses, it was observed that these reasons were associated with the limited number of nurses $(63.8 \%)$, insufficient knowledge and practice about professional ethical values $(44.3 \%)$, lack of practical training in the ethical decision-making process of the clinic (32.1\%), improper attitudes of healthcare professionals towards ethics (35.7\%), lack of mechanisms available for assessing the ethical situations $(32.1 \%)$ and inadequate sense of teamwork among those working in the unit (36.7\%).

Table 1: Ethical Experiences of Pediatric Nurses

\begin{tabular}{|l|l|l|}
\hline & $\mathrm{n}$ & $\%$ \\
\hline Frequency of Encountering Ethical & & \\
Problems & 42 & 21.0 \\
$\quad$ Frequently & 148 & 74.0 \\
Occasionally & 10 & 5.0 \\
Never & & \\
\hline
\end{tabular}

\begin{tabular}{|l|l|l|}
\hline Ethical Problems Encountered* & & \\
Medications & 14 & 6.3 \\
Giving information about the & 92 & 41.6 \\
disease & 27 & 12.2 \\
Care practices & 46 & 20.8 \\
All & & \\
\hline $\begin{array}{l}\text { Feel Sufficient in Realizing and } \\
\text { Solving Ethical Problems }\end{array}$ & & \\
Yes & 127 & 63.5 \\
No & 20 & \\
Undecided & 53 & 10.0 \\
& & 26.5 \\
\hline
\end{tabular}

* Multiple options marked.

A large percentage of the pediatric nurses $(70.1 \%)$ reported that they had sufficient information about ethics, $43.5 \%$ stated that they were capable of solving an ethical problem through their own assessment of the problem and by soliciting the views of team members, while 34\% relied on their own professional experiences and personal assessments to solve these problems. Most of the nurses (81.4\%) emphasized the necessity of being given ethical lessons during nursing training.

The mean moral sensitivity of the total score obtained by the pediatric nurses was determined to be at a medium level $(95.89 \pm 24.34)$ (Min:37, Max:188). In comparing the demographic characteristics and total MSQ scores of the pediatric nurses, a significant difference was found between the age groups and total MSQ scores of the nurses $(\mathrm{KW}=8.858, \mathrm{p}=0.012)$. In the Bonferroni corrected Mann-Whitney U test performed to determine which group was responsible for the difference, it was concluded that nurses aged 41 and older had higher moral sensitivities compared to the nurses aged 18-30 ( $\mathrm{U}=-2.925$, $\mathrm{p}=0.003)$ and $31-40(\mathrm{U}=-2.670, \mathrm{p}=0.008)$. Moreover, a significant difference was determined between the number of years the nurses had work and their total MSQ scores $(K W=10.443$, $\mathrm{p}=0.015$ ), where it was observed that nurses who had been working for 21 years or more had higher moral sensitivities compared to the nurses who had been working for between 1-5 years $(\mathrm{U}=-2.533, \mathrm{p}=0.011)$ and for between 6-12 years $(\mathrm{U}=-2.651, \mathrm{p}=0.008)$. In the study, no statistically significant difference was determined 
between the gender, marital status, educational MSQ scores ( $p>0.05)$ (see Table 2). background, status of having children and total

Table 2: The Mean MSQ Score of Pediatric Nurses in Terms of Certain Demographic Characteristics.

\begin{tabular}{|c|c|c|c|c|c|}
\hline Characteristic & $\mathrm{n}$ & $\%$ & $\begin{array}{l}\text { MSQ } \\
\mathrm{X} \pm \text { SD }\end{array}$ & Analysis & $\mathrm{p}$ \\
\hline $\begin{array}{l}\text { Age* } \\
\qquad 18-30 \text { (a) } \\
31-40 \text { (b) } \\
41 \text { and older (c) }\end{array}$ & $\begin{array}{l}107 \\
76 \\
17\end{array}$ & $\begin{array}{l}53.5 \\
38 \\
8.5\end{array}$ & $\begin{array}{l}98.12 \pm 25.68 \\
96.26 \pm 22.75 \\
80.11 \pm 16.46\end{array}$ & $K W=8.858$ & 0.012 \\
\hline $\begin{array}{l}\text { Gender } \\
\text { Male } \\
\text { Female }\end{array}$ & $\begin{array}{l}22 \\
178\end{array}$ & $\begin{array}{l}11.0 \\
89.0\end{array}$ & $\begin{array}{l}100.86 \pm 22.29 \\
95.27 \pm 24.57\end{array}$ & $\mathrm{U}=-1.389$ & 0.165 \\
\hline $\begin{array}{l}\text { Marital Status } \\
\text { Married } \\
\text { Single }\end{array}$ & $\begin{array}{l}116 \\
84\end{array}$ & $\begin{array}{l}58.0 \\
42.0 \\
\end{array}$ & $\begin{array}{l}95.47 \pm 25.56 \\
96.46 \pm 22.67\end{array}$ & $t=-0.286$ & 0.775 \\
\hline $\begin{array}{l}\text { Status of Having Children } \\
\text { Children } \\
\text { No children }\end{array}$ & $\begin{array}{c}93 \\
107\end{array}$ & $\begin{array}{l}46.5 \\
53.5\end{array}$ & $\begin{array}{l}93.83 \pm 23.49 \\
97.74 \pm 25.16\end{array}$ & $\mathrm{t}=-1.125$ & 0.262 \\
\hline $\begin{array}{l}\text { Educational Background } \\
\text { High School } \\
\text { Associate Degree } \\
\text { Undergraduate and postgraduate }\end{array}$ & $\begin{array}{l}38 \\
43 \\
119\end{array}$ & $\begin{array}{l}19 \\
21.5 \\
59.5\end{array}$ & $\begin{array}{l}96.32 \pm 24.60 \\
95.98 \pm 24.71 \\
95.71 \pm 24.32\end{array}$ & $\mathrm{~F}=0.009$ & 0.991 \\
\hline $\begin{array}{l}\text { Working Years** } \\
1-5 \text { years }(\mathrm{a}) \\
6-12 \text { years }(\mathrm{b}) \\
13-20 \text { years }(\mathrm{c}) \\
21 \text { years or more }\end{array}$ & $\begin{array}{l}93 \\
41 \\
48 \\
18\end{array}$ & $\begin{array}{l}46.5 \\
20.5 \\
24.0 \\
9.0\end{array}$ & $\begin{array}{l}98.72 \pm 25.03 \\
101.44 \pm 27.58 \\
90.46 \pm 20.15 \\
83.06 \pm 15.93\end{array}$ & $K W=10.443$ & 0.015 \\
\hline
\end{tabular}

$*_{\mathrm{c}}<\mathrm{a}, \mathrm{b}$

$* * \mathrm{~d}<\mathrm{a}, \mathrm{b}$

Comparison of the demographic characteristics and MSQ subscale scores of the pediatric nurses in the study showed a statistically significant difference between age groups and the scores obtained on the autonomy $(\mathrm{KW}=6.175, \mathrm{p}=0.046)$, practice $(\mathrm{KW}=9.569, \mathrm{p}=0.008)$ and orientation subscales (KW=9.666, $\mathrm{p}=0.008)$. The 41-year old and over age group had lower scores on the subscales of autonomy, practice and orientation; female nurses had statistically significant lower scores $(\mathrm{U}=-2.378, \mathrm{p}=0.017)$ on the holistic approach subscale compared to male nurses; and nurses with children had statistically significant higher moral sensitivities on the subscale of orientation $(\mathrm{t}=-2.267, \mathrm{p}=0.024)$. A significant difference was determined between the number of years nurses had been working and scores on the autonomy $(\mathrm{KW}=8.409, \mathrm{p}=0.038)$, practice (KW: 13.348, $\mathrm{p}=0.004$ ) and orientation (KW=11.571, $\mathrm{p}=0.009)$ subscales. Nurses who had been working for 13 years or longer had lower scores on the subscales of autonomy, practice and orientation. No statistically significant difference was found between marital status and educational background and the MSQ subscale scores ( $p>0.05)$ (see Table 3). 
Moral Sensitivity, Ethical Experiences and Related Factors of Pediatric Nurses - Fatma Tas Arslan, Pelin Calpbinici

Table 3: Comparison of the Demographic Characteristics and MSQ Subscale Scores of Pediatric Nurses

\begin{tabular}{|c|c|c|c|c|c|c|}
\hline $\begin{array}{l}\text { Demographic } \\
\text { Characteristics }\end{array}$ & Autonomy & Benevolence & $\begin{array}{l}\text { Holistic } \\
\text { Approach }\end{array}$ & Conflict & Practice & Orientation \\
\hline $\begin{array}{l}\text { Age } \\
18-30(a) \\
31-40(b) \\
41 \text { and older (c) } \\
\text { Test and p }\end{array}$ & $\begin{array}{l}22.38 \pm 7.83 \\
21.18 \pm 6.55 \\
17.35 \pm 6.80 \\
c<a, b \\
K W=6.175 \\
p=0.046\end{array}$ & $\begin{array}{l}13.82 \pm 4.46 \\
14.33 \pm 4.56 \\
11.65 \pm 3.99 \\
\\
K W=4.357 \\
p=0.113\end{array}$ & $\begin{array}{l}14.80 \pm 6.24 \\
14.72 \pm 5.83 \\
12.53 \pm 3.37 \\
\\
K W=1.651 \\
p=0.438\end{array}$ & $\begin{array}{l}12.07 \pm 3.50 \\
12.42 \pm 3.25 \\
12.35 \pm 3.51 \\
\\
\mathrm{KW}=0.171 \\
\mathrm{p}=0.918\end{array}$ & $\begin{array}{l}13.12 \pm 4.41 \\
12.00 \pm 4.06 \\
9.71 \pm 4.40 \\
\mathrm{c}<\mathrm{a}, \mathrm{b} \\
\mathrm{KW}=9.569 \\
\mathrm{p}=0.008\end{array}$ & $\begin{array}{l}11.43 \pm 5.03 \\
10.47 \pm 4.93 \\
7.76 \pm 3.31 \\
c<a, b \\
K W=9.666 \\
p=0.008\end{array}$ \\
\hline $\begin{array}{l}\text { Gender } \\
\text { Male } \\
\text { Female } \\
\text { Test and p }\end{array}$ & $\begin{array}{l}23.00 \pm 6.97 \\
21.31 \pm 7.42 \\
U=-1.085 \\
p=0.278\end{array}$ & $\begin{array}{l}14.50 \pm 3.80 \\
13.75 \pm 4.58 \\
U=-0.979 \\
p=0.328\end{array}$ & $\begin{array}{l}17.10 \pm 5.54 \\
14.27 \pm 5.89 \\
U=-2.378 \\
p=0.017\end{array}$ & $\begin{array}{l}11.73 \pm 2.90 \\
12.29 \pm 3.45 \\
U=-0.847 \\
p=0.397\end{array}$ & $\begin{array}{l}13.09 \pm 3.65 \\
12.32 \pm 4.45 \\
U=-1.024 \\
p=0.306\end{array}$ & $\begin{array}{l}12.09 \pm 4.70 \\
10.59 \pm 4.97 \\
U=-1.614 \\
p=0.107\end{array}$ \\
\hline $\begin{array}{l}\text { Marital Status } \\
\text { Married } \\
\text { Single } \\
\text { Test and p }\end{array}$ & $\begin{array}{l}21.09 \pm 7.79 \\
22.07 \pm 6.76 \\
t=-0.932 \\
p=0.352\end{array}$ & $\begin{array}{l}13.87 \pm 4.78 \\
13.77 \pm 4.11 \\
t=0.150 \\
p=0.881\end{array}$ & $\begin{array}{l}14.68 \pm 5.97 \\
14.44 \pm 5.84 \\
t=0.284 \\
p=0.777\end{array}$ & $\begin{array}{l}12.49 \pm 3.24 \\
11.87 \pm 3.59 \\
t=1.281 \\
\mathrm{p}=0.202\end{array}$ & $\begin{array}{l}12.30 \pm 4.47 \\
12.55 \pm 4.25 \\
t=-0.392 \\
\mathrm{p}=0.696\end{array}$ & $\begin{array}{l}10.41 \pm 4.98 \\
11.24 \pm 4.90 \\
t=-1.175 \\
p=0.241\end{array}$ \\
\hline $\begin{array}{l}\text { Status of Having } \\
\text { Children } \\
\text { Children } \\
\text { No children } \\
\text { Test and p }\end{array}$ & $\begin{array}{l}20.85 \pm 7.30 \\
22.14 \pm 7.47 \\
t=-1.228 \\
p=0.221\end{array}$ & $\begin{array}{l}13.70 \pm 4.56 \\
13.95 \pm 4.50 \\
t=-0.399 \\
p=0.691\end{array}$ & $\begin{array}{l}14.16 \pm 5.58 \\
15.00 \pm 6.16 \\
t=-0.996 \\
p=0.320\end{array}$ & $\begin{array}{l}12.39 \pm 3.18 \\
12.08 \pm 3.59 \\
t=0.631 \\
p=0.529\end{array}$ & $\begin{array}{l}11.98 \pm 4.17 \\
12.72 \pm 4.52 \\
t=-1.188 \\
p=0.236\end{array}$ & $\begin{array}{l}9.89 \pm 4.46 \\
11.48 \pm 5.29 \\
t=-2.267 \\
p=0.024\end{array}$ \\
\hline $\begin{array}{l}\text { Educational } \\
\text { Background } \\
\text { High School } \\
\text { Associate Degree } \\
\text { Undergraduate and } \\
\text { postgraduate } \\
\text { Test and p }\end{array}$ & $\begin{array}{l}21.50 \pm 6.52 \\
20.81 \pm 8.28 \\
21.75 \pm 7.33 \\
F=0.251 \\
\mathrm{p}=0.778\end{array}$ & $\begin{array}{l}13.26 \pm 4.72 \\
14.19 \pm 4.65 \\
13.88 \pm 4.39 \\
F=0.442 \\
p=0.643\end{array}$ & $\begin{array}{l}15.29 \pm 5.70 \\
15.05 \pm 5.94 \\
14.18 \pm 5.96 \\
F=0.673 \\
p=0.511\end{array}$ & $\begin{array}{l}11,82 \pm 3,56 \\
12,16 \pm 3,36 \\
12,39 \pm 3,37 \\
F=0.415 \\
\mathrm{p}=0.661\end{array}$ & $\begin{array}{l}12.66 \pm 4.08 \\
11.77 \pm 4.69 \\
12.55 \pm 4.36 \\
\mathrm{~F}=0.588 \\
\mathrm{p}=0.556\end{array}$ & $\begin{array}{l}12.08 \pm 4.85 \\
11.47 \pm 5.00 \\
10.08 \pm 4.89 \\
F=2.976 \\
p=0.053\end{array}$ \\
\hline $\begin{array}{l}\text { Working years } \\
1-5 \text { years (a) } \\
6-12 \text { years (b) } \\
13-20 \text { years (c) } \\
21 \text { years or more } \\
\text { (d) } \\
\text { Test and } p\end{array}$ & $\begin{array}{l}22.58 \pm 7.43 \\
22.73 \pm 7.99 \\
19.52 \pm 6.51 \\
18.39 \pm 6.25 \\
\\
\mathrm{c}, \mathrm{d}<\mathrm{a}, \mathrm{b} \\
\mathrm{KW}=8.409 \\
\mathrm{p}=0.038\end{array}$ & $\begin{array}{l}13.88 \pm 4.20 \\
14.56 \pm 4.82 \\
13.77 \pm 4.84 \\
12.06 \pm 4.14\end{array}$ & $\begin{array}{l}15.14 \pm 6.36 \\
15.95 \pm 6.38 \\
13.17 \pm 4.84 \\
12.33 \pm 3.31\end{array}$ & $\begin{array}{l}11.96 \pm 3.35 \\
12.46 \pm 3.56 \\
12.77 \pm 3.13 \\
11.67 \pm 3.99\end{array}$ & $\begin{array}{l}13.29 \pm 4.48 \\
12.95 \pm 4.19 \\
10.98 \pm 3.50 \\
10.61 \pm 5.01 \\
\text { c, } \mathrm{d}<\mathrm{a}, \mathrm{b} \\
\mathrm{KW}=13.348 \\
\mathrm{p}=0.004\end{array}$ & $\begin{array}{l}11.47 \pm 5.04 \\
11.66 \pm 5.20 \\
9.52 \pm 4.66 \\
8.28 \pm 3.21 \\
\mathrm{c}, \mathrm{d}<\mathrm{a}, \mathrm{b} \\
\mathrm{KW}=11.571 \\
\mathrm{p}=0.009\end{array}$ \\
\hline
\end{tabular}




\section{Discussion}

After examining the ethical experiences of nurses, it was determined that a large part of them occasionally encountered ethical problems. Results showed that most of the ethical problems the nurses faced involved informing families about their children's diseases (41.6\%), followed by care practices and medications. In other similar studies, Başak et al.(23) stated that ethical problems were experienced by $47.7 \%$ of nurses, while $\mathrm{Ha}$ mric (24) reported that they were experienced by 45\%. Van der Arend and Remmers-Van Den(25) observed in their study that $62.4 \%$ of nurses encountered ethical problems, especially regarding care (71.2\%). Aksu and Akyol(20) reported that nurses mostly experienced ethical dilemmas regarding medications, whereas De Veer et al.(26) found that nurses experienced ethical problems pertaining to care practices and informing patients.

The present study determined that more than half of the nurses considered themselves adequate in recognizing and solving ethical problems and believed that they had sufficient information about ethics. Given the further development of professional experience and a critical viewpoint, these nurses can be expected to improve upon their success in solving ethical problems. A large majority of the pediatric nurses (43.5\%) in the study expressed that they could solve ethical problems through their own assessments of ethical situations and by soliciting the views of team members. Penticuff and Walden(27) in their studies determined that $94 \%$ of nurses discussed particular issues with their colleagues and that $25 \%$ brought ethical issues before the ethics committee. Kim et al.(28), on the other hand, reported that $65.3 \%$ of nurses consulted their colleagues and that $60.6 \%$ tried to solve ethical problems by applying their personal values. In another study conducted on this topic, nurses were found to most likely handle these issues by discussing them with nursing peers $(86.9 \%)$ and nursing leaders (70.4\%), while $47 \%$ of the nurses reported that they would discuss the issue with the patient's doctor and only $41 \%$ indicated that they would discuss the issue with another professional (29). In studies conducted in Turkey, Uyer et al.(29) determined that a majority of nurses $(45.1 \%)$ consulted with their colleagues in solving ethical problems; Çobanoğlu and $\operatorname{Algıer(10)~reported~}$ that nurses tried to solve ethical problems with the help of doctors; and $\mathrm{Avc1}(8)$ found that $44 \%$ of nurses conducted their own self-assessment of the ethical problem and developed solutions based on their professional experiences and personal values. Ethical principles and models serve as guides in adopting the proper moral attitudes when deciding on a course of action. In this study, it was observed that ethical principles and models did not play a governing role in the decisions pediatric nurses made according to their own assessments of ethical problems they encountered in the clinical environment.

The pediatric nurses attributed the main reasons for their experience of ethical problems to the limited number of nurses and to insufficient knowledge and practice about professional ethical values. Studies in the literature were in agreement with these findings (30-32).

A large number of the pediatric nurses underlined the necessity of including ethics lessons in nursing training. In support of this view, Jonhstone et al.(33) reported that a majority of the nurses $(74 \%)$ in their study believed that they were in need of more education on ethical issues. Indeed, ethics lessons are certainly indispensable in nursing training, insofar as they will help to cultivate ethical decision-making skills and facilitate the competence of nurses in this field. Nursing schools in Turkey provide ethics lesson and information about ethical subjects.

The total mean score obtained by the pediatric nurses on the moral sensitivity questionnaire administered in this study was determined to be $95.89 \pm 24.34$, the result of which shows that pediatric nurses had moderate moral sensitivity levels. In the study conducted with intensive care nurses by Başak et al.(23), the mean score of moral sensitivity was found to be $97.66 \pm 18.38$, while in Tazegün's(19) study conducted with pediatric nurses, the mean score on moral sensitivity was determined to be $93.80 \pm 19.10$. Furthermore, in two studies that were conducted with clinical nurses, the mean score on moral sensitivity was found to be $85.23 \pm 18.84$ in the study by To$\operatorname{sun}(22)$ and $102.46 \pm 4.306$ in the study by Aksu 
and Akyol(20). Moral sensitivity is an important attribute for determining the ethical problem. Therefore, high moral sensitivity enables pediatric nurses to determine and solve ethical problems.

In another finding from this study, older pediatric nurses (older than 41) were observed to have higher moral sensitivities. This result is supported by the studies conducted by Lutzen et al.(34), LeinoKilpi et al.(35), Kulju et al.(36), and Huang et al.(37). The present study also compared the age groups of pediatric nurses and subscales of MSQ, where it was determined that the levels of moral sensitivity derived from the subscales of autonomy, practice and orientation rose in parallel with the increase in the ages of the nurses. One might argue that "older" nurses have accumulated experience in handling difficult moral conflicts, both in nursing practice and in their personal lives, and thus have higher developed moral sensitivity(38). In confirmation of this, the study results show that moral sensitivity increased along with the increase in professional experience and age. Considering these results, the fact that more than half of the nurses in the study were young and less experienced professionally may have contributed to the problems they experienced in distinguishing and solving the ethical problems they encountered.

In the study, a significant difference was determined between the number of years the nurses had been working and the total scores on the MSQ. Pediatric nurses who had longer years of working experience had higher moral sensitivities. Additionally, it was observed that the moral sensitivity levels, as determined in the subscales of autonomy, practice and orientation, increased as the nurses' number of working years increased. Further, it was found that the number of professional working years was associated with the development of moral sensitivity, a finding similar with a number of study results. In the study by Başak et al.(23), autonomy was shown to develop as the number of working years increased. According to Tosun(22), the sensitivities of nurses rose along with the increase in the number of working years. Similarly, Ersoy et al.(39) reported that longer durations of professional work experience was effective in making the right decision. In stark contrast, Öztürk et al.(40) stated that as the number of working years increased, the moral sensitivities decreased on the holistic approach subscale. Savaşkan(41), in his study, determined no statistically significant difference between the number of professional working years and moral sensitivity, and likewise, $\operatorname{Avc1}(8)$ found no statistically significant difference between the number of professional working years and ability to determine and solve ethical problems.

The study's female nurses were found to have higher holistic approaches and moral sensitivities compared to their male counterparts. To$\operatorname{sun}(22)$, in his study, reported that higher scores obtained by female nurses on the benevolence subscale were associated with the maternal instinct of female nurses. According to the moral development theory of Gilligan, which happens to be in agreement with the results of the present study(43), women and men have different ways of socializing and show differences in terms of ethical development. The study by Lutzen et al.(43) reveals one of these differences, as they reported that female nurses from different settings had higher moral sensitivity in the investigated sub-scale dealing with aspects of moral meaning. In another study, female participants scored significantly higher on a majority of the investigated factors of moral sensitivity(44). Furthermore, a meta-analysis of gender differences in moral sensitivity suggested that gender differences in moral sensitivity exist irrespective of the instrument used to measure moral sensitivity(45). While the meta-analysis included studies from various settings and contexts, all nonetheless indicated that women and men may express their moral sensitivity in different ways and, above all, that moral sensitivity is a complex phenomenon consisting of many factors (38).

Comparing the total score on MSQ and the status of having children in pediatric nurses, it was observed that nurses with children were more sensitive, according to the orientation subscale. In agreement with the present study, the study by $\operatorname{Tosun}(22)$ found that nurses with children had higher scores on the subscales of practice and orientation, the result of which could be associated with the fact that there was a greater number of women among the nurses and therefore the motherhood role of women was more apparent. 


\section{Conclusion}

Pediatric nurses encounter situations involving ethical problems in clinical practices more frequently as science and technology advance. The present study determined that a large majority of pediatric nurses encountered ethical problems, and that nurses had a moderate level of moral sensitivity, which was correlated with the ages of the nurses and the number of years they had been working. As ethical decision-making plays a very important role in pediatric nursing, ethics training should be included in both bachelor degree curriculums and nursing trainings offered in professional life. Additionally, it is recommended that practical exercises regarding the decision-making processes in clinics and discussions about the ethical issues be provided.

\section{Conflicts of interests}

The authors have no conflicts of interest to declare.

\section{References}

1. Schluter J, Winch S, Holzhauser K, Henderson A. Nurses' moral sensitivity and hospital ethical climate: a literature review. Nursing Ethics 2008; 15(3): 304-321.

2. Hatcher T. Environmental ethics as an alternative for evaluation theory in for profit business context. Evaluation and Program Planning 2004; 27: 357-363.

3. Botes A. A comparison between the ethics of justice and the ethics of care. Journal Advanced Nursing 2000; 32(5): 1071-1075.

4. Burkhardt MA, Nathaniel AK. Ethics \& issues in contemporary nursing. 3th. ed. Thomson Delmar Learning: Canada; 2007.

5. Gürhan N. Hemşirelik ve etik (Nursing and ethics). Conference: 1st National Medical Ethics. Kocaeli, Turkey; 1999.

6. Torjuul K, Sorlie V. Nursing is different than medicine; ethical difficulties in the process of care in surgical units. Journal Advanced Nursing 2006; 56(4): 404-413.

7. Katsuhara Y. What moral requirements cause ethical dilemmas among nurse executives. Japan Journal of Nursing Science 2005; 2: 57-65.

8. Avcı K. Pediatri alanında hemşirelerin etik sorunların çözümüne yönelik yaklaşımlarının incelenmesi (Investigation of the nurses' approach to the solution of the ethical issues in pediatric area). Ankara, Turkey: Hacettepe University; 2007.

9. Twycross A, Powls L. How do children's nurses make clinical decisions? Two preliminary studies. Journal of Clinical Nursing 2006; 15: 1324-1335.

10. Çobanoğlu N, Algıer LA. Qualitive analysis of ethical problems experienced by physicians and nurses in intensive care units in Turkey. Nursing Ethics 2004; 11(5): 444-458.

11. Rustan CH. Ethics and palliative care in pediatrics. American Journal of Nursing 2004; 104(4): 54-65.

12. Hughes S. Ethical theories and dilemmas. British Journal of Perioperative Nurse 2000; 12(6): 211-221.

13. Carnevale F. Ethical consideration pediatric nursing. Revista Da Sociedade Brasileira De Enfermeiros Pediatras 2012; 12(1): 37-47.

14. Engelhard DV. Tibbın gündelik yaşamında etik araştırmadan terapiye disiplinler yelpazesi (Ethik im alltag der medizin spektrum der disziplinen zwischen forschung und therapie). Trans: Namal A. Istanbul: Nobel Tip Kitapevi; 2000.

15. Esen B. Yenidoğan yoğun bakım ebe ve hemșirelerin etik ikilemleri ve mesleki profesyonellik düzeyleri ile ilișkisi (The relationship between ethical dilemmas and occupational profession levels of neonatal intensive care nurses and midwifes). Istanbul, Turkey: Marmara University; 2013.

16. Borhani F, Abbaszadeh A, Mohamadi E, Ghasemi E, Hoseinabad-Farahani MJ. Moral sensitivity and moral distress in Iranian critical care nurses. Nursing Ethics 2015; 28:1-9.

17. Ertug N, Aktaș D, Faydali S, Yalçin O. Ethical sensitivity and related factors of nurses working in the hospital settings. Acta Bioethica 2014; 20(2): 265-270.

18. Yeom HA, Ahn SH, Kim SJ. Effects of ethics education on moral sensitivity of nursing students. Nursing Ethics 2016; 24: 1-9.

19. Tazegün A. Çocuk hemşirelerin etik duyarlılık düzeyleri ve etkileyen faktörler (Ethical sensitivity levels of pediatric nurses and the factors affecting this sensitivity). Erzurum, Turkey: Atatürk University; 2013.

20. Aksu T, Akyol A. İzmir'deki hemşirelerin etik duyarlılıklarının incelenmesi. (Investigation of the moral sensibility of nurses in İzmir). Turkiye Klinikleri Journal of Medical Ethics 2011; 19(1): 16-24. 
Moral Sensitivity, Ethical Experiences and Related Factors of Pediatric Nurses - Fatma Tas Arslan, Pelin Calpbinici

21. Lutzen K, Nordin C. Conceptualisation and instrumentation of moral sensitivity in psychiatric nursing practice. International Journal of Methods in Psychiatric Research 1994; 4(4): 241-248.

22. Tosun H. Sağlık bakımı uygulamalarında deneyimlenen etik ikilemlere karşı hekim ve hemşirelerin etik duyarlılıklarının belirlenmesi (Determining sensitivity of the nurses and the physicians against the ethic dilemmas which experienced at the health care practices). İstanbul, Turkey: İstanbul University; 2005.

23. Başak T, Uzun S, Arslan F. Yoğun bakım hemşirelerinin etik duyarlılıklarının incelenmesi (Investigation of the moral sensibility of intensive care nurses). Gülhane Tip Dergisi 2010; 52(3): 76-81.

24. Hamric BA, Blackhall LJ. Nurse-physician perspectives on the care of dying patients in intensive care units: Collaboration, moral distress and ethical climate. Critical Care Medicine 2007; 35(2):422-429.

25. Van der Arend AJG, Remmers-Van Den CHM. Moral problems among Dutch nurses: A survey. Nursing Ethics 1999; 6(6): 468-482.

26. De Veer AJ, Francke AL, Struijs A, Willems LD. Determinants of moral distress in daily nursing practice: A cross sectional correlational questionnaire survey. International Journal of Nursing Studies 2013; 50: 100-108.

27. Penticuff JH, Walden M. Influence of practice environment and nurse characteristics on perinatal nurses' responses to ethical dilemmas. Nursing Research 2000; 49(2): 67-72.

28. Kim YS, Park JW, You MA, Seo YS, Han SS. Sensitivity to ethical issues confronted by Korean hospital staff nurses. Nursing Ethics 2005;12: 595-605.

29. Uyer G, Algıer L, Akan N, Hanoğlu Z. 1999. Doktor ve hemşirelerin etik kararı gerektiren durumlara yaklaşımları (Doctors and nurses approach to ethical decision requiring status). In Çoruh, M, Ed. Toplam Kalite Yönetimi Prensiplerinin Sağlık Hizmetlerinde Uygulamalar, p. 121-140.

30. Pauly B, Varcoe C, Storch J, Newton L. Registered nurses perceptions of moral distress and ethical climate. Nursing Ethics 2009; 16(5): 561-573.

31. Zuzelo PR. Exploring the moral distress of registered nurses. Nursing Ethics 2007; 14(3): 344-359.

32. Bunch EH. High technology and nursing: ethical dilemmas nurses and physicians face on high-technologyunits in Norway. Nursing Inquiry 2002; 9: 187-195.

33. Jonhstone MJ, Da Costa C, Turale S. Registered and enrolled nurses' experiences of ethical issues in nursing practice. Australian Journal of Advanced Nursing 2004; 22(1): 24-30.

34. Lutzen K, Johanson A, Nardüstrom G. Moral sensitivity: Some diferences between nurses and pyscicians. Nursing Ethics 2000; 7(6): 520-529.

35. Leino-Kilpi H, Suominen T, Mäkelä M, Mc Daniel C, Puukka P. Organizational ethics in Finnish intensive care units: Staff perceptions. Nursing Ethics 2002; 9(2): 126-136.

36. Kulju K, Suhonen R, Leino-Kilpi H. Ethical problems and moral sensitivity in physiotherapy: a descriptive study. Nursing Ethics 2013; 20(5): 568-577.

37. Huang FF, Yang Q, Zhang QH, Khoshnood K, Zhang JP. Cross-cultural validation of the moral sensitivity questionnaire-revised Chinese version. Nursing Ethics 2015; 22: 1-10.

38. Tuvesson H, Lützén K. Demographic factors associated with moral sensitivity among nursing students. Nursing Ethics 2016; 28: 1-9

39. Ersoy N, Göz F. The ethical sensitivity of nurses in Turkey. Nursing Ethics 2001; 8: 299-312.

40. Öztürk H, Hintistan S, Kasım S, Candaş B. Yoğun bakım ünitelerinde hekim ve hemşirelerin etik duyarlılığı (Ethical sensitivity of physicians and nurses in intensive care units). Yoğun Bakım Hemşireliği Dergisi 2009; 13(2): 77-84.

41. Savaşkan F. KKTC’ deki yataklı tedavi kurumlarında çalışan hemşire ve hekimlerin hasta haklarına duyarlılığının belirlenmesi (Determination of sensitivity on patient right of nurses and phsysicians working at public hospitals in TRNC). Istanbul, Turkey: Istanbul University; 2006.

42. Gilligan C. Male orientation and moral development. In: Kittay E, Meyers, D, ed. Women and moral theory. Cambridge: Harvard University Press; 1987.

43. Lutzen K, Blom T, Ewalds-Kvist B, Winch S. Moral stress, moral climate and moral sensitivity among psychiatric professionals. Nursing Ethics 2010; 17(2): 213-224.

44. Borhani F, Keshtgar M, Abbaszadeh A. Moral self-concept and moral sensitivity in Iranian nurses. Journal of Medical Ethics and History of Medicine 2015; 8(4): 1-7.

45. You D, Maeda Y, Bebeau MJ. Gender differences in moral sensitivity: a meta-analysis. Ethics and Behavior 2011; 21(4): 263-282.

Received: June 20, 2016

Accepted: November 24, 2016 